\title{
The Twilight Zone of Positive and Natural Law
}

\begin{abstract}
Helen Silving*
The conflict of "positivism" and "natural law" is not merely of doctrinal concern. Conceptually, this conflict develops in several stages: from a purely theoretical, jurisprudential stage, through an ethical-ideological stage, to a practical political stage, and each of these stages is marked by the evolution of certain ideas and ideals of democratic thought and action. Concepts such as "inherent rights," "reasonableness" and "equal protection" can be understood only in the light of this conflict and its potential resolution. The essential of democracy, "government of laws," as government by positive law, is but a symbol of the final, political stage of positivism. The purpose of this article is to sketch both the meaning and the theoretical and practical import of the conflict of positive and natural law.
\end{abstract}

I

POSITIVE AND NATURAL LAW AS RELATIVE CONCEPTS

There are two basic approaches to "natural law," one oriented to its "substance," the other to the "method" of finding it. As in philosophy generally, so in the philosophy of law, the human mind turned outward before it turned inward: attention was first centered on the inherent "nature" of natural law, its objective attributes or its innate "substance," and only later on a subjective factor, the possibility, method or procedure of its cognition. The first conception of natural law assumes that such law exists independently of its being recognized or found by anyone or declared in any particular procedure. Within this conception, natural law may demand that positive law conform to certain procedural standards, e.g., due process, but natural law itself is not bound by any form. An incident of its imdependence of form is breadth of scope. The "natural law" of God or of Reason is potentially limitless. Although there are many systems of such natural law, and although these systems vary in content and conflict with each other, each of them claims to possess absolute-that is, eternal and universal-vahidity. Little can be added to the voluminous literature dealing with the controversy over this conception of "natural law," whether it be divine or rationalistic. From a rational point of view, its existence, truth or self-evidence can be neither affirmed nor demed, and hence is not a proper subject of dispute. Scientifically, such "natural law" may be considered

* Member, New York Bar; Research Associate in Law, Harvard Law School. 
only in two respects. Legal history can evaluate the immeasurable influence which belief in such law has exercised on the development of legal ideas and institutions. Analytical legal science can show what legal rules are contained in legislative enactments which use terms based on the jurisprudence of such natural law.

The second conception of natural law results from a critical approach to legal phenomena. This approach begins with the assertion that no legal system can be described as "absolute" unless it is infallible, and that, in turn, for any legal system to be infallible, there must be an "infallible way of knowing what it [is]." Natural law, within this realistic view, concerned with finding and applicability rather than with the "brooding" metaphysical existence of law, is defined negatively, namely, by its contrast to positive law. Thus cast, the problem would seem to invite a definition of positive law, and such definition is known to vary in different legal systems and divergent jurisprudential theories. However, only one attribute of positive law is relevant in the present context. It is characteristic of positive law that it prescribes the sources in which its rules may be found and the methods whereby such rules may be found or new rules created. Any substantive rule which may be considered within positive law but is not present in such specific sources or any procedure which may be adopted but is not yet in use is natural law. In other words, at any given time, positive law is "present law," natural law is potential "new law," meaning a new rule of law or a new form of law creation or finding.

This definition must meet two objections, one directed at the concept of positive law upon which it is predicated, the other concerned with the scope of natural law thus evolved. One might deny the quality of positiveness to a legal system which satisfies but the rudimentary test of being a system that prescribes the standards of its own existence and development. It may be correctly said that this definition takes no account of the crucial problem of positiveness, namely, efficacy. It is believed, however, that in the present context, concerned merely with the delimitation of positive and natural law, the suggested description of the former is sufficient ${ }^{2}$ in that it defines the area to which natural law is external. The difference between positive and natural law, thus drawn, is relative. A rule or an institution may be positive within a given system of law but not within another, and, within an identical system, it may be natural at one time and positive at another. For instance, in England and in the United States, stare decisis is part of the.positive law of the land, whereas in countries of the civil law,

1 Pollock, in I Holares-PolIock LetTers 275 (Howe ed. 1946).

2 As will be seen in the following section, additional features of positive law may be significant when its distinction from natural law is discussed within a context other than that of a mere delimitation. 
judgments rendered in individual cases are not sources of "Law" in the same sense. Also, the views as to the classification of decisions as "Law" within a system of positive law may change in time. In the present context, it is solely relevant that whatever may be included in the term "positive law" within any hypothetical system, anything potentially to be considered by it and yet external to it is natural law.

At this point, the second objection must be faced: natural law, thus conceived, comprises potentially everything except, of course, the subjects contained in the limited field of positive law. One might-it will be saidas well divide the universe into positive law and nature. Of course, such a reductio ad absurdum is not intended to be conveyed by the suggested division into positive and natural law. Rather, this division proceeds from the experience that there is in the life of the law, at any time, and varying in time and from country to country, an area of potential consideration. This means that there are, sociologically speaking, certain rules which, while they have not yet, and, indeed, may never, become part of positive law, have a chance of finding acceptance into the law. These rules are distinct from those which have no such chance whatever, and sociological study may single them out from the great mass of rules which are merely conceptual, rather than real, possibilities. Moreover, such study may estimate the degree of chance that a particular rule of natural law will become incorporated into positive law. Simple examples may demonstrate the scope of the first-mentioned sociological study. It is possible to visualize that in future English or American law the function of juries will be limited, but it is not conceivable that the medieval system of torture will be introduced. Or, in terms of substantive law, it is imaginable that taxes will be reduced or increased beneath or beyond the present level, but it is not likely that all taxation will be abolished. The second-mentioned type of sociological study is somewhat more dubious in the sense that its chances of success are indeterminate. Depending on the sociological and political climate of a particular country at a particular period, certain rules of natural law may be closer to or nuore remote from incorporation into positive law, and, depending on the available data and the efficiency of sociological method, it may be possible to estimate-or, perhaps, only guess at-the chance of such incorporation.

Realistic "natural law," as here defined, is a relative concept both from the standpoint of its relation to positive law and from the standpoint of its varied content. Not only may the same rule be positive within one system and natural from the point of view of another, or positive at one time and natural at another, but the precepts of natural law are not constant. They are neither a-historical nor non-geographic, but vary from time to 
time and from place to place. This is also true of the various types of "absolute natural law" as a group. Each such law styles itself as eternal and universally valid. However, since there are many "absolute natural laws," and since human belief in any of them is neither constant nor universal, they are, from a realistic point of view, merely distinctive forms of relative natural law.

Apart from the situation which would prevail in the entirely hypothetical "state of nature," positive law and natural law are coexistent. Indeed, strictly speaking, there can be no natural law unless there is some form of rudimentary positive legal organization in relation to which natural law may be "natural." The relationship between these laws varies in accordance with the attitude of positive law toward the phenomenon of natural law. Under the terms of a particular system of positive law, its sources of finding law or its methods of finding or creating law may be exclusive. Where such rules prevail, natural law being found or created in contravention to them, is necessarily "revolutionary." Absent such exclusiveness in terms, there may be inchoate sources and methods of law creation and finding, and hence varying forms of natural law.

Where sources and methods of law other than those prescribed by positive law are neither barred nor specifically authorized by the terms of such law, "natural law" is not revolutionary but "tolerated." In this instance it constitutes a present reservoir of potential rules which might be absorbed by positive law at some future time. Where such absorption occurs other than by an act of formal declaration that a certain rule or system of rules is henceforth to be regarded as law, the process of incorporation may be gradual, and the exact state of transformation of natural into positive law may be uncertain. It is often difficult to discern whether or not or to what extent a rule of natural law has found acceptance in positive law. ${ }^{4}$ Thus, law.

3 There may be mstances where positive law excludes not all but only some types of natural

4 What, for instance, is the status of stare decisis in continental European countries? Where exactly in the area between positive and natural law should a judicial decision, or two or more uniform judicial decisions, but less than a long line of consistent decisions, be classified?

Precedents are undoubtedly binding where there has developed a "jurisprudence constante" or "staendige Rechtsprechung," that is, a consistent line of decisions. The rule pronounced in these decisions is conceived of as one of customary law. See e.g., Colin Et Capitant, I Traitit de Droit CivIr 100 (rev. by De la Morandière, 1953), ENNECCERUS-NIPPERdex, Allgemeiner TEIT DEs BUERGeritchen Rechts 162, 168 (14th rev. ed. 1952). In Germany, the Law concerning the Organization of Courts (Gerichtsverfassungsgesetz), text of September 12, 1950 (BuNDESGESETZBLATT 513), provides for a procedure intended to secure consistency of decisions of the various divisions of the Bundesgerichtshof (the highest court of the Bonn Republic in civil and criminal matters). Sections 136, 137, lex cit. By statutory fiat, the decisions of the Federal Constitutional Court (Bundesverfassungsgericht) are in certain cases binding in the same manner as are statutes. On this see note 72 infra. In Austria, a Supreme Resolution (Allerhoechste Entschliessung) of August 7, 1872 provides for the recording of certain decisions of 
there may be varying degrees of positiveness in the law. In this sense, again, it may be said that the difference between positive and natural law is relative. ${ }^{5}$

Apart from "natural law" in the sense of the reservoir of sources and methods which are tolerated, that is, neither authorized nor barred, by positive law, there are other resources of law which may be described as "natural law." These are rules to be established by an authorized procedure but not generally defined as to substance. Positive law may delegate to certain of its officers the authority of finding law, without identifying or specifying the sources from which such law may be derived. This may be termed "delegated" natural law. It is law positive as to procedure but natural as to content. Typical of such delegation of natural law is a rule calling upon the judge to apply, as the standard of lawful conduct, the behavior of "the reasonable man." The "reasonable man" is a composite phenomenon. Positive law states who shall determine how a reasonable man is supposed to behave, without specifying in clear and definite terms

Oberster Gerichtshof (highest court in civil and criminal matters) in the so-called "Spruchrepertoriztm" and the "Judicatenbuch." The Law of February 24, 1907 (RETCHSGESETZBLATT 41) provides that recorded decisions may be overruled only in a prescribed manner. It is important to note that these provisions are statutory, and thus more rigid than are the rules governing stare decisis in common law countries. But beyond such provisions, a single decision is said not to constitute a precedent, meaning that it is not binding. Judicial decisions are not mentioned among the "sources of law" in either the Italian Civil Code art. 1 or the Swiss Civil Code art. 1, and in the Austrian Civil Code $\$ 12$ they are expressly declared not to constitute a source of law. In Germany the $B$ indesgerichtshof recently declared that judicial decisions are not legally binding. See decision cited and discussed infra, at notes 70 et seq. In a decision rendered December 20, 1953 [4 ARs 47/53, reported in NEUE JURISTISCHE WOCHENSCHRIFT 510 et seq. 1954], it refused to follow a decision of the Federal Constitutional Court. Nevertheless, judicial decisions, especially those of higher courts, are normally followed. On the extent to which decisions are binding in continental European countries see von Mehren, The Judicial Process in the United States and in Germany, I FestschrIFT FUER ERNST RABEL 67 (1954).

On the other hand, the extent of the binding force of statutes is also varying in time and from country to country. Can a statute become obsolete by non-use? In Germany, it has been said that customary law has the same force and effect as a statute and hence can repeal or amend an older statute. See ENNECCERUS-NIPPERDEX, op. cit., 165. This means that where failure to apply a statute for a long time is accompanied by an opinio necessitatis, that is, a conviction that such failure to apply the statute is right or lawful, it operates in the same manner as repeal by legislative act. In France, the question of repeal by non-use was controversial in the beginning of the nineteenth century. It has been since settled that the non-use cannot effect a repeal. See Darloz, Nouveau Répertorre de Droit (1948), title "Lois et Décrets," itein 49. In the United States a similar position was adopted in District of Columbia v. Thompson Co., 346 U.S. 100, 114 (1953), note 88 infra.

5 "Revolutionary law," meaning natural law that is barred by a particular system of positive law, is also frequently transformed into positive law in spite of the prohibition. It is sometimes difficult to determine at what point the "revolution" has become so sweeping as to warrant the statement that the system of positive law has completely changed its character and, in fact, is no longer identical with the system previously in force. At any fixed time, however, the law that is barred cannot be regarded as a potential subject of consideration. 
the group of persons he is to represent or the method whereby the normal behavior of the group is to be established. The judge has discretion to apply the term "reasonable man" to an inchoate group of human types and to determine the average behavior of the chosen group. Because the group and the method of establishing its normal behavior is not predetermined, the standard may be described as "natural," in contrast to positive. In the case of the "reasonable man," there occurs, as a rule, a gradual transformation of the natural law element involved into positive law. Judicial precedent renders the pattern of the reasonable man specific in defining a described course of conduct as "reasonable" or as "unreasonable," thereby in effect creating positive rules of "reasonableness." In the course of progressive judicial specification, the "reasonable man" develops from a "natural" phenomenon to a set of legal rules of conduct. Eventually, he appears to become almost a shorthand expression for describing the set of legal rules. However, in a growing civilization it can never be said with certainty that all incidents of the "reasonable man" pattern have been definitively fixed. New and unpredictable situations arise, for which there is no analogy in prior decisions. To that extent, the "reasonable man" must always remain a phenomenon of natural law.

Beyond the element of "natural law," resulting from the inchoate nature of the methods and sources of law which serve as the judge's reservoir of selection in the last described case, there is an additional element of "natural law" implied in this instance. It emerges on the periphery of delegated power and pertains to the form of delegation. Whereas the legislator delegated to the judge authority merely to "find" law, the judge, instead of "finding," actually created such law. Nor could he have done otherwise, for there was no law to be found. Did the judge then violate the terms of delegation? Perhaps, in a formal sense, but since he was bound to decide in the case at bar, the violation was an act of necessity. Even had the legislator expressly forbidden the judge from creating law rather than finding it, while at the same time forcing him to decide the case, the prohibition would have to be frustrated. ${ }^{6}$ This necessity is one implied in the nature of law, and thus superimposed on all positive law. It is what might be called "jurisprudential natural law."

The two elements of natural law best represented in the example of the "reasonable man" may be found also, though perhaps to a less marked degree, in any form of delegation to find or interpret law. To the extent that

6 Of course, "logically," it might be conceivable for the judge, in such case, to refuse decision rather than violate the terms of delegation. This applies even where a refusal to decide constitutes a "denial of justice," for which the judge might render himself hable (French Civil Code art. 4). However, were judges to resort to such a device fairly frequently, the life of the law would be seriously impaired. The "necessity" of deciding is lience, while not technically a "logical" one, a "necessity" imphed in legal development. 
interpretation is "free," that is, not bound by legal rules, the judge always creates law where he is specifically authorized merely to "find" it. True, there is only a himited number of interpretations which may be applied, for instance, to the words of a statute, and judicial interpretations are also limited by the fact that they are subject to test by appeal and public criticism. Moreover, it can hardly be denied that, as a general rule, judges are earnestly endeavoring to "find" the ineaning of a statute before them rather than to create it. There is, however, in every act of interpretation an area of judicial freedoin or discretion, such as, of necessity, must exist between a general concept and its apphication. To the extent that it exists, the judge performs an original creative act rather than a merely reproductive function of finding preexisting law. ${ }^{\text {? }}$

On the other hand, there may be found in law instances of a phenomenon converse to that described above, in which natural law parades under the guise of positive law to be "found." Jurists have a tendency to

7 All that has been said applies similarly to the so-called "finding of facts" in law. As in the interpretation of statutes, so in the construction of facts, there is implied an element of necessary creativeness. As we do not absolutely know whether the objective meaning of a statute is identical with that imposed upon the statute by an interpretative decision, so we are also never absolutely certain whether facts, as they actually occurred, are identical with those that are "found" to have occurred by a court or a jury. See FRANK, CourTs ON TRIAL (1949).

There is, nevertheless, a tendency even in contemporary doctrine to maintain the distinction between creating and "finding" law. This distinction has been recently alleged in Germany to afford the dividing line between "discretion" and a "vague or uncertain statutory term," which are at present in the limelight of interest since the revival of the administrative court system. The theory is advanced that in the case of delegation of "discretion" by the legislator to a law enforcement agency, there are several proper answers available, from which the agency might select the one it thinks best according to its subjective "value judgment," whereas in the case of filling statutory gaps or interpreting vague and uncertain statutory terms, there is only one correct answer which the agency must "find" in the exercise of its "cognitive power." See recently Redding, Unbestimmter Rechtsbegriff oder Ermessen, DrE OEFEENTITCHE VERWAITUNG 365 (1954); Schindler, Unbestimmter Rechtsbegriff oder Ermessen, MoNATSSCHRIFT FUER DEUTSCHES RECHT 331 (1954). However, in reality, the distinction is merely a technical and procedural one, pertaining to the method of operation and to the division of powers in government. In the first instance, the agency might use sociological factors rather than the established methods of statutory interpretation, whereas in the second instance, it preferably will use such devices as legislative history. In the first instance, there will be a tendency on the part of a reviewing court to consider itself as bound by the agency determination, whereas in the second instance, the court feels free to substitute its own decision for such determination. But, of course, it would be entirely proper for the agency, in exercising "discretion," to consider the purpose of the statute in the hight of its legislative history. Moreover, "discretion" is also, to some extent, reviewable. So far as the use of "natural law" resources is concerned, the distinction is not an essential one, in that "finding" in law is never a purely "cognitive" process, just as perhaps-as we wonld like to believe-a "value judgment" in law is not a purely subjective element. There is certainly nothing inherent in the nature of a question which renders it specifically a inatter of discretion or specifically a matter of "finding" the correct statutory rule. 
term as "natural law" rules which have long since been preempted by positive law. They speak of "natural rights of men" even where all the incidents of these one-time natural rights have since been well defined and circumscribed by positive legal rules and thus have ceased to be "natural." This type of law may be termed "apparent natural law." 8

However, just as it can never be said with certainty that all incidents of "reasonableness" in the pattern of the "reasonable man" have been permanently frozen, so it cannot be said with respect to certain systems of "natural rights" adopted by legislation that they are completely closed and incapable of expansion. ${ }^{.}$There remain in both instances areas of genuine "delegated natural law," which may become significant as new, and hitherto undetermined, situations arise.

Among such "natural human rights" there is a group which is distimguishable from other types of "delegated natural law," and may, by virtue of its distinctive qualities, be described, in a special, technical, legal sense, as "absolute natural law."

The statement that the existence of a substantive, absolute "natural law" or "natural right" cannot be proved or denied by scientific means does not imply that the concept of such "law" or "right" is legally meaningless. When enunciated in a legal source, such "law" or "right" may have a significant legal meaning. The declarations of rights contained in constitutional documents are important legal realities, notwithstanding the fact that they are not actual realities in a scientific sense. The fallacy contained in the enunciation of these rights consists in the fact that they are proclaimed as preexisting realities, inherent in nature or reason, whereas they are actually rights created by the legal proclamation that enacts them into law, albeit, at times, with retroactive effect. However, as thus enacted, they have a distinctive substantive legal character, flowing from the fact that at the time of enactment they were conceived as "natural" rather than "positive" rights. Implicit in this conception is a broad and comprehensive

8 The story of the "natural law" doctrine of the Austrian Civil Code is most instructive. This code refers to the interpretation of statutes "in accordance with natural principles of law." \$ 7. Section 16 states: "Every man has innate birthrights that are evident through the medium of reason. ..." The framers of the code undoubtedly intended to incorporate into its terms the ideas of natural law and natural rights prevailing at the time of enactment. At present, these terms are interpreted to consist of rules and rights which are not laid down in any particular statutory provision but may rather be inferred from the entire statutory system. See I Krang, Kommentar ZuM AIrgemeinen Buergertichen Gesetzbuch 130 (2nd rev. ed. 1948).

9 The Austrian system is no longer one of "natural rights" in a technical sense. It should be noted, however, that, even in the light of contemporary interpretation, it grants the judge a broad discretion, based on the original idea of such rights. The concept of principles derived not from a particular statutory provision but from the totality of certain provisions undoubtedly enlarges the scope of judicial discretion. 
rather than a narrow and legalistic rule of legal interpretation. The fact that these rights were understood to be ingrained in Reason or in Nature affects their legal character and scope. They are not merely specific "rights" visualized by a legislator ${ }^{10}$ but fundamental legal philosophies, ways of legal thinking. The Copernican turn of thought accomplished in the natural rights philosophy of the French Revolution consisted in replacing specific feudal "liberties" by one "liberty," specific "equalities" by one "equality." The same doctrine, together with all its philosophical implications, was current in the United States. It was expressed in the Declaration of Independence, and again enunciated, on November 19, 1863, in the Gettysburg Address, which visualized "a new nation conceived in liberty and dedicated to the proposition that all men are created equal." 11 The 14th Amendment, which guaranteed to all citizens "equal protection," became law less than five years later. While, today, no one would seriously contend that we are "created equal," the philosophy implicit in this phrase would still seem to be pertinent to the interpretation of the Amendment formulated at a time when that philosophy was current. For the term "equal," at the time when used, conveyed a distinctive "jurisprudence," and that jurisprudence, in turn, expressed a legal rule to be followed. "Equality" meant the "natural rights of equality," and these rights, when translated into positive legal terminology, meant any and all incidents of equality rather than specific rights or remedies. ${ }^{12}$

However, in the recent historic decision of the Supreme Court of the

10 Indeed, it is highly dubious that the "intention" of the legislators with regard to such rights can ever be regarded as sufficiently definite to be relevant or that it should be considered even where it is clearly expressed. If the framers of such rights had any definite "intention" with regard to the subject matter of enactment, such "intention" was merged in the language they used, in its then current meaning. At the time of enactment, this language was not equivocal in the hight of the then prevailing philosophy. There is, therefore, no need now, as there was no need then, to resort, as is being done in the United States, to legislative history in order to explain it. Where rights contained in the Constitution are concerned, the doctrine of interpreting statutes in accordance with the specific intent of the legislator, as evidenced by preparatory works, is particularly inapposite. These rights are not ordinary expressions of representative legislative will, but portions of the organic law, which is the ultimate source of all government functions; their meaning should not be made dependent on anything a legislator might have said. In other respects, the interpretation of the Constitution has been judicially held to be governed by distinctive rules. Prigg v. Pennsylvania, 41 U.S. (16 Pet.) 536 (1842); Smith v. Allwright, 321 U.S. 649, 665 (1944). For a discussion of interpretation in accordance with the "intention" of the legislators, see Silving, A Plea for a Law of Interpretation, 98 U. PA. L. REv. 499 (1950).

11 Emphasis added.

12 Such method of interpretation does not imply intellectual acceptance of the doctrine of natural law but merely calls for technical utilization of that doctrine as a carrier of a legislative message. It is the task of lawyers to present that message to courts by subuntting a "jurisprudential brief," showing what philosophy of law was expressed in certain legal terms and what legal rule was conveyed by the medium of that philosophy. 
United States, interpreting the "equal protection" clause of the 14th Amendment, Brown v. Board of Education, ${ }^{13}$ there is no mention of "natural law" or "natural rights," although the result in the case is the same as might have been reached had these concepts been used as means of interpretation. Since the Amendments were written, positivism - under the powerful influence of Justice Holmes-prevailed in the United States to such an extent that absolute "natural law" no longer seems to have any place in legal argument or in a judicial decision. And this equally applies to the use of such "natural law" not in the sense of an original philosophy of law but as a mere nedium of understanding past legislation. ${ }^{14}$

The "absolute natural law," as above interpreted, contains more elements of positive law than do other types of delegated natural law, for it implies less judicial discretion. The legal rule implicit in the philosophy of natural rights instructs the judge to give these rights the broadest possible application. To the extent that it limits his discretion in choosing the proper scope of their application, "absolute natural law" is "apparent natural

13347 U.S. 483 (1954), holding segregation in public schools unconstitutional, since in contravention to the "equal protection" clause of the 14th Amendment. The court pointed out that the significance of education lias grown since the Amendment was enacted and since the cited case was decided. It held that, while the legislative listory of the Amendment is inconclusive, that Amendment, when applied to the contemporary significance of education, required abolishment of segregation. This, of course, presupposes that the Amendment had potentialitics which may not lave been directly, visualized at the time of enactment in the light of the then prevailing conditions.

14 That the taboo against natural law, extending even to its acceptance as a historical fact expressed in positive legal enactments, is unjustified, may be easily demonstrated. In construing the authority conferred upon the judge to apply a concept such as "equal," two possible roads are theoretically open. The judge may assume that this term has the meaning and scope to which the legislator seems to have addressed himself specifically, subject, however, to the variations that are inherent in the growth of technical civilization. Or, he may assume that the legislator also visualized a growth of culture and took account of changing views as to the character and the incidents of the idea of "equality" itself. Perluaps the best illustration of the former type of delegation may be found in a statute interpreted to confer equality in using public transportation, enacted at a time when airplanes were as yet unknown. Though he was unaware of the future existence of such means of transportation, it is mostly assumed that the legislator "intended" to include it. An example of the latter type of delegation would be authorization to give new scope to the concept of "equality." The legislators, for instance, may not have anticipated developments in modern psychology and sociology, developments bringing to our attention the hitherto unnoticed effects upon individuals of certain types of discrimination. That they may have, nevertheless, "intended" to confer autliority to include in the concept of "equality" new incidents, is considered as, at least, doubtful. In reality, the "intent" of the legislators was not specifically directed cither to airplanes or to new equality incidents, and it is rather difficult to understand on what ground the distinction as to legislative intent is drawn in contemporary interpretation. The fact is that legislators rarely deal expressly with the problem of delegation to agencies entrusted with the function of interpretation. Indeed, they are ordinarily unaware of its existence. That is particularly true of the "natural rights" legislator, who believed that all problems pertaining to "natural riglits" might be solved by recourse to reason or "self-evidence."

The interpretation of "equal protection" suggested here is neither as broad as that applied to the due process clause by the majority in Rochin v. People of California, 342 U.S. 165 (1952), 
law." It is genuine "natural law" to the extent that the judge finds new, and litherto unnoticed or undetermined, incidents of application.

Positive "natural law" may also develop by judicial action, independently of any positive constitutional document. This presupposes current belief in such law-a phenomenon whicl may be mostly observed in times of legal or constitutional crisis. In Germany, for instance, as a result of the total collapse of reliance on positive law, which accompanied the breakdown of the National Socialist regime and the Nuremberg Trials, there is now emerging a revival of natural law..$^{15}$ That revival, under the slogan of "super-legal" or "super-constitutional law," pervades both classroom and courtrooin. It has been recently highlighted in a landmark decision of the Federal Constitutional Court of the Bonn Republic. ${ }^{16}$ Citing Radbruch,

nor as narrow as that advanced by the minority view (see Mr. Justice Black and Mr. Justice Douglas, concurring, pp. 174 et seq.) in the same case. It is essentially an historical interpretation, based on the realization that the framers of the equal protection clause beheved that "equal protection" was sufficiently defined by the "nature" of equality itself, so that there was no diffculty in "finding" wherein "equality" consisted. They thought that they were freezing "equality" in "reason," which to thein was not a vague and indefinite but a very precise term. We inust not forget that they lived in the Age of Reason, not in the Age of Sociology or in the Age of Psychology.

Unless "equal protection" of the 14th Amendment is interpreted in the light of the "natural rights" doctrine prevailing at the time of enactment, it is indeed difficult to discover the conceptual ground on which the Segregation Cases were decided. Professor Sutherland in his article, Segregation by Race in Public Schools Retrospect and Prospect, LAw AND CONTENP. Рвов. 169, 177 (1955), therefore, correctly associates the words of the decision with Locke's writings. As Professor Cahn's article, $A$ Dangerous Myth in the School Segregation Cases, 30 N.Y.U.L. REv. 150 (1955), wisely demonstrates, rationalization of the decision by reference to modern developments in psychology is inadequate, for it suggests that the meaning of the Constitution changes with changes in psychological doctrine. Moreover, making the question of segregation vel non dependent on the Negro citizens' reaction to it obscures the moral as well as the constitutional issue involved. Segregation by legal fiat is immoral and unconstitutional regardless of consent. Man's digmity can be neither waived nor forfeited by failure to resent insults.

15 Natural law in present day Germany is not merely a jurisprudential micety but part of every-day law. As noticed by Darmstaedter in Naturrecht und Positives Recht, Deursche RichterzeItuNg 109-110 (1952): "Twenty years ago, no one would have dared in Germany to submit to a law review dedicated to practical law and its exposition a discussion of natural law. In the meantime, the revival of natural law, announced in 1936 by Heinrich Rominen in his book 'Die ewige Wiederkehr des Naturrechts' (The Eternal Return of Natural Law), seems to have become a reality to an extent never before dreamed of." The reasons of that revival are said to be "contact with the world of Anglo-American law . . . which had been particularly stirring in the clash over the Nuremberg Trials; the dire social and economic situation in Germany, whose needs could not be adequately met by a pan-logical law; the growing selfassurance of the lawyer, striving for freedom from bureaucratic confinement and for achievement of an ethical autonomy; and, finally, ... recognition that only a law centered around self-government of the autonomous will based on natural law can successfully oppose the totalitarian idea of State."

10 Decision rendered on December 18, 1953, 3 Entsclyeidungen des Bundesverfassungsgerichts 225 et seq. (1954) (cited BVerfG. 3, 225). 
the court declared that, in the interest of legal security, a conflict between a positive legal enactment and substantive justice is normally resolved in favor of the former; however, where "the discrepancy between a positive statute and justice reaches an intolerable degree ... the statute, being 'wrong law,' must yield to justice." The court said that this also applies to rules of constitutional law, so that a provision of the written Constitution may be found to be "unconstitutional constitutional law."17 With regard to the nature of "super-legal" or "super-constitutional" law, the court merely said that such law may or may not be incorporated in positive legal enactments, but that, whether or not so incorporated, it overrides all other provisions, even constitutional, and that "super-constitutional law" consists of principles, such as that of legal security, which, notwithstanding the equality in rank of all constitutional provisions, may be said to be supreme tenets of constitutional law. The court did not describe the source whence such law may be derived. It did not say whether it is a law ingrained in reason, in human conscience, in the moral convictions or actual mores of society, in the Volksgeist, in legislation as a whole, in the spirit of legislation, in the conscience of individual judges or in any other of the numerous sources of natural law developed in the course of history. ${ }^{18}$ Thus, at the present stage, "super-legal law" of the German constitutional doctrine is genuine "delegated natural law," in a very broad sense, for its meaning

${ }_{17}$ Indeed, the issue before the court was whether, as suggested by the Intermediate Appellate Court of Frankfurt a.M., a provision of the Bonn Constitution (Art. 117, providing that legislation which conflicts with the rule of equality of men and women shall remain in force pending enactinent of implementing legislation, "but not beyond 31 March 1953") is unconstitutional, in that, in the absence of implementing legislation, it delegates legislative authority to courts.

18 The terminology of the court is derived from Stammler's vocabulary. The use of such words as "right law" indicates that the court may have adopted his philosophy of natural law as a basis. On the other hand, it would appear from the context of the case that the court was, in fact, dealing with rather realistic problems of constitutional law, which in our system of jurisprudence are normally disposed of under the heading of "due process." While holding Art. 117 constitutional as applied to Marriage and Family Law, the court indicated that a statute, even "constitutional," which is unduly vague, so that it actually delegates legislative power to courts, would be unconstitutional.

Natural law, in the form of "inherent rights," has been also recognized in the American constitutional doctrine. Butchers' Umion Co. v. Crescent City Co., 111 U.S. 746 (1884). But no suggestion has ever been made that there may be a conflict between such law and the Constitution itself.

Outside the realm of constitutional law, German courts have repeatedly held invalid positive legislation at variance with fundamental principles of justice. In declaring that Nazi discriminatory legislation was not "law" and that reliance upon it affords no excuse in a criminal case, the Bundesgerichtshof defined the essential features of "superior law." Decision rendered on December 19, 1952, BGH. 1 Strafsenat. Urt. v. 19. Dec. 1952 g. M.-1 StR 2/52, reported in 3 ENTSCHEIDUNGEN DES BUNDESGERICITSHOFES IN STRAFSACHEN 358 et seq. (1953) (cited BGHSt. 3, 358), citing a previous decision, BGHSt. 2, 234. The court said: ". . the freedom of a State to determine, within its territory what shall and what shall not be law, is not 
and scope are as yet unsettled. ${ }^{19}$ Since it is conceived in positive law itselfin a decision of the Constitutional Court having authority to declare legal rules unconstitutional-as capable of overthrowing provisions of the written Constitution, it is, in a sense, "positive revolutionary law."

II

\section{THE CONFIICT OF POSITIVE AND NATURAI LAW}

For the purpose of delimiting natural from positive law, it is sufficient to define the latter, as has been done in the preceding section, as a system which prescribes the rules of its own development. However, in attempting to resolve or, at least, understand the ultimate conflict of the two systems, it is necessary to have a more specific definition. It is submitted that for the purpose of dealing with that conflict, the most workable definition of positive law is its description as the law which is endowed with a specific machinery of enforcement and is im fact obeyed and enforced.

Proceeding from this definition of positive law, we may face the problem of its conflict with natural law. That conflict, actually both a fighting war of arms and institutions and a cold war of nerves, has been waged for centuries for the conquest of the word "law." One might reasonably ask why it should be important for either positive or natural law to acquire exclusive dominion over that simple linguistic term. The reason lies in the fact that the word "law" has acquired a strange, almost magical, power over the minds of men. Without having a clear conception of the import of the word, men see in it a symbol of authority. That authority, indeed, is vaguely felt to be one to which they must react by way of an inner compulsion. Conscious and unconscious legitimists and law reformers, in turn, attempt to utilize that state of mind for their political aims, each asserting whatever he wishes to be obeyed or enforced to be "law" or exclusive "Taw." The so-called "positivists" claim only that to be "law" which is in fact obeyed and enforced, whereas adherents of "natural law" of various types and denominations claim only that to be "law" which conforms to a chosen idea of "natural justice." In the course of the so-called "life of the

unlimited. Notwithstanding all differences that exist between municipal legal systems, there is in the consciousness of all civilized nations a certain central core of law wlich, in common legal opinion, must not be violated by any statute or by any other authoritative action. It comprises certain principles of luuman conduct-developed in the course of time by all civilized nations on the basis of concurrent ethical ideas - which are deemed inviolable and legally bimding even where the legal system of a particular State does not expressly exclude them from the area in which the State may exercise arbitrary power."

10 In the above cited decision of the Constitutional Court (see note 16 supra), the suggestion has been made that the scope of "unconstitutional constitutional law" is extremely limited. Only in very rare cases will the court make use of its power to declare a constitutional provision unconstitutional. 
law," this conflict is being resolved daily in that, in concrete instances, concepts of natural law either prevail or lose. Where they prevail, they become part of positive law and are thenceforth also acceptable to the positivists. Where they are rejected, of course, they continue to be a subject of argument.

Since the described conflict, while theoretically a war over words, is, practically, a war for power, there is no scientific device for its ultimate resolution. Even if it were possible to establish a perfectly positivist system of law, it would take all the effort of totalitarian thought control to prevent people from alleging or thinking that only "natural law" is true law. On the other hand, if it were possible to establish a umiversally recogmized system of "natural law," meaning a system of such law which is at the same time obeyed and enforced everywhere, there would be no way of stopping positivists from alleging that this indeed is true law, because it is positive.

In this war, which is essentially a war of ideologies rather than of ideas, it might be logical to expect the positivists to yield. For it is they who claim that their position is a purely scientific one, whether it be "purely" positivist, realistic or phenomenological. Indeed, a leading realist, Judge Jerome Frank, has forcefully advocated such capitulation. He proposed that the term "law" be eliminated from scientific juristic discussion. ${ }^{20}$ Theoretically, his arguments are unanswerable. ${ }^{21}$ The term "law," having been abused to an extent where it is almost meamingless, is no longer workable for scientific purposes, and there is truly no point in continuing to use it. ${ }^{22}$ Why is this logical proposal not acceptable? Partly, because the term "law" does

\footnotetext{
20 Frank, Courts on Triat 66 et seq. (1949).

21 In his recent book, JURISPRUDENCE: MEN AND IDEAS OF THE LAW 68 n. 9 (1953), Professor Patterson criticizes Judge Frank's argument against the use of the term "law," pointing out that Judge Frank does use the term "legal," which would seem to be inconsistent. I do not believe this criticism to be well founded. While logically a derivative of the term "law," "legal" has not partaken of the ideological evolution of "law." When saying that a conduct is "legal" or "Tawful" or "illegal" or "unlawful," men hardly try to convey the idea that such conduct does or does not conform to natural justice or "moral law." The separateness of the terms "law" and "legal" can be easily demonstrated. The term "law" is used to denote not only rules of human conduct but also uniformity of natural events, implied in the term "laws of nature." Indeed, the concept of a "law of nature" as an order governing the physical universe is the pattern for the concept of "natural law" as moral law inherent in nature (even though, originally, it may have been the religious or moral law which set the pattern). But one does not use the term "legal" to denote conformance to, or the term "illegal" to denote departure from, the law governing the physical universe. Words originating in a common root often have a different fate in the course of the history of language and of ideas.

22 Of course, there is some merit in Morris R. Cohen's [COHEN, REASON AND LAw 65 et seq. (1950)] rejection of "the complacent assumption that there can be only one true or correct definition of any object," and in his proposition that there may be different proper definitions of the word "law." Cohen points out that for the purpose of study in any field it is necessary "to create a definite point of view or perspective for the organization of our subject matter,"
} 
occur in law itself, and law and legal science are not clearly separated..$^{23}$ Partly, because, as things are, yielding the term "law" would amount to an implied political concession. If the positivists were to abandon the field of "law," that field would be immediately preempted by natural law. Having no definition of "law" of their own, they would have no standard or test for asserting that "natural law" is not "law," other than that the term is devoid of any meaning. The latter test, of course, is a rather inadequate weapon in a struggle over the future of our rules and institutions, a struggle, actually, over what different people wish these rules and institutions to be. Thus, the history of the word "law" dooms positivism, an historical product of the political ideology of a "government of laws," to remain a political theory. It should be remembered that juristic positivists are mostly lawyers, engaged not only in the pursuit of knowledge but also in the daily contest over law enforcement and law reform. In a conflict between their scientific consciences and their loyalty to what happens to be their side of a case, the latter will invariably prevail. Thus, not only "the life of the law" but also "the hife of jurisprudence" proves to be "not logic but experience."24

Of course, positivist jurisprudence has as little a priori or "natural" right to claim only positive law to be "law" as natural law jurisprudence has to claim that only that positive law which conforms to natural justice is "law." What, in the face of this situation, may positivist jurisprudence and natural law jurisprudence legitimately demand? I believe that, speaking in ternns of Kelsenian theory, ${ }^{26}$ they may each claim preservation of the "purity" of the chosen system.

and that "[f]rom this point of view we must condemn all definitions of law ... as that which is right, just, expresses the will of the majority, safeguards the social welfare or security, etc." He does not explain, however, why it is necessary to use the "confusing" term "law" for the purpose of a study whose scope is artificially limited.

23 The law itself uses legal science, thereby transforming such science into a rule of conduct. See text supra at notes 11 and 12 . The process of transformation is, in turn, a subject with which legal science must deal.

24 Of course, Justice Holmes' famous statement, that "the life of the law has not been logic; it has been experience," is a paradox. In order that a sense-datum might become an "experience," some "Iogic" is necessary. Beyond that, logic is necessary to make the "experience" a legal experience, as distinguished from a physical, esthetic or any other experience. For criticism of the paradox see CoHEN, REASON AND LAw 3 (1950).

25 It is equally true that they may both have such a right. If the term "law" is defined arbitrarily, each may formulate its definition independently of the other. On the other hand, if any of these jurisprudential theories should rely on the common use of the term, it would have to demonstrate that its definition is, at least, the prevailing one. No sociological study has been made which might show what is actually the prevailing use of the word "Iaw."

26 See KEISEN, REINE RECHTSLEHRE (1934). While I do not accept Professor Kelsen's essential postulate that only "positive law" should be described as "Iaw"-a postulate which Kelsen admits to be arbitrary-I beheve that his theory is the only one susceptible of delimiting the areas of "positive" and "natural" law, and thus describing the nature of the conflict of the two laws. 
Experience shows that natural law and positive law not only raise conflicting claims to exclusive dominion over the word "law," but that they also, more or less consciously, invade each other's narrower domain. Natural law frequently parades as positive, whereas positive law often asserts to be "natural" or "just" law. In introducing a novel rule of natural law into positive law, a judge will often state that this rule is by no means new but has always been part of the law of the land. Or, he will interpret the words of a statute in a novel manner, claiming that the meaning thus introduced into the statute has been there at all times. On the other hand, a positivist will occasionally advance ethical justifications for individual legal rules or for obedience to law in general, and he may even go so far as to assert that it is just or right to obey unjust law. These claims are more specific than the mere assertion that the rule being advanced is "law," meaning a rule commanding obedience. The natural law adherent will thus claim that the particular rule of natural law which is in issue is "positive law," meaning that it is part of that law which is being obeyed, such as the common law or the statutory law. ${ }^{27}$ The positivist, on the other hand, may assert that a rule of positive law is part of "natural law," in the sense of being inherently ethical. The respective claims may be alleged to be inaccurate. The positivists are entitled to say that the judge's statement in the above example is scientificaly inaccurate, and the adherents of natural law may say that the stated claim of the positivist is unjustified from the point of view of a chosen ethical system. "Purity of system" thus implies that the positivists may point out where natural law has made a false pretense at being part of positive law, and that, vice versa, the adherents of natural law may demand that positive law should not pretend that it conforms to their ethical postulates. ${ }^{28}$

After having made the described statement, the positivist should stop. As a man of science, he has unmasked a scientific inaccuracy, and he should now leave any demands for "action" to the lawyer and the law reformer. However, experience shows that hardly any positivist has ever stopped at this point. Most positivists proceed from there to specific instructions addressed to the judge. The principal positivist instruction is of an ethical rather than of a scientific nature; it requires the judge not to announce as a preexisting part of positive law a precept which has not been,

27 of course, the distinction between the assertion that a rule is "law" and the assertion that it is "positive law" is rarely clear-cut.

28 It should be noted that the assertions of the positivists and those of the adherents of natural law are of a fundamentally different nature. The assertions of the former are objective, meaning that they purport to state scientific facts. Those of the latter are subjective, in that they proceed from a presupposed idea of ethics. Such idea, of course, may be claimed to bo objective, in the sense of being universally true or valid. 
in fact, part of such law. This instruction is most emphatic where the natural law thus challenged takes the form of a unversally valid, infallible natural law, in the conventional sense of the term. In this instance, it is indeed based on the "scientific" view that such law has no existence as an objective reality and is not open to inquiry by the specific methods of science.

This positivist "instruction to the judge," however, is, when taken as an a priori postulate, not as "positivist" as it would appear to be at first blush. For it involves a jurisprudential imterference with "the hife of the law." Unless the law itself accepts the scientific doctrine advanced by positivism, jurisprudence, as a science of the law, when introduced imto the law from the outside, is itself a form of "natural law." There is nothing inherent in the law which requires it to be logical, reasonable or scientific. ${ }^{29}$ Only where a particular legal system prohibits the use of non-positivist reasoming can the described "instruction to the judge" be said to be but a reproduction or scientific description of the positive system in issue. For only then is it a legal instruction, properly reflected in positivist science. Any positivist jurisprudence which goes beyond such scientific finding belies the fact that positive law itself tolerates and even delegates all kinds of natural law, including at times even the alleged-perhaps "non-existent" -eternally valid, infallible "natural law" of God or of Reason. This tolerance or delegation, wherever it occurs, is a present feature of positive law which must not be ignored by positivist jurisprudence. Nor should it escape truly positivist scientific observation that there are twilight zones between positive and natural law, where it is often difficult to establish whether or not a rule or idea of natural law has already become part of that actually obeyed and enforced system which is defined as positive law.

When positive law is viewed, not in its static form, as the law which is currently obeyed and enforced or the law as it appears at any particular date, but as positive law in flux, it also must be realized that much of the "revolutionary natural law" of yesterday is part of the positive law of today. This phenomenon frequently results from the fact that many a positive law supplies the tools for the introduction of revolutionary law. Particularly where a system of law contains contradictory rules, an opening is made for what may be termed a partial revolution. One of two contradictory rules is a priori doomed to be violated even by the legitimate agents of the law. In addition, revolution of "substantive law" is always implicitly delegated, to the extent that fallible human agents are procedurally authorized to find it. ${ }^{30}$ Also, history records respectable positive

29 On the scope of logic inherent in law see Sec. III infra.

30 "Jurisdiction to decide is jurisdiction to make a wrong as well as a right decision." Pope v. United States, 323 U.S. 1, 14 (1944). 
legislation which expressly recognizes-or legalizes in advance-revolutionary law. The Magna Charta, it will be recalled, gave the barons, "together with the community of the whole land," a legal right to fight royal oppression by rebellion against the king, to wit, "distress us in all possible ways, namely, by seizing our castles, lands, possessions, and in any other way they can ... to molest us to the utmost of ... [their] power." In fact, perhaps, there was no need for the framers of the Declaration of Independence to resort to "self-evident truths" for justification of secession, for they had in the Great Charter a perfectly valid legal basis for that action. The glorified natural right of resistance to oppression, or the "right of insurrection," was at one time part of positive French constitutional law..$^{31}$ As late as 1946 it was included in a draft of a French Constitution. ${ }^{32}$ The Constitution of the Land Hesse of December 1, 1946 proclaims resistance against an unconstitutional use of authority to be everybody's right and duty. ${ }^{33}$ Respectable jurists have held the right of insurrection to be exercisable even against a procedurally unimpeachable action of duly authorized government agents. ${ }^{34}$

One might legitimately inquire why it is at all important to separate positive and natural law even to the extent of maintaining their "systematic purity." 35 The simplest answer to that question is, from the positivist's

31 The French Constitution of 1795 (Art. 35 of the Declaration of Rights) declared that "when the government violates the rights of the people, insurrection is, for the people and for each portion of the people, the most sacred of [all] rights and the most indispensable of [all] duties."

${ }^{32}$ The first project of the present French Constitution of 1946 contained a similar provision (Art. 21): "When the government violates the liberties and rights guaranteed by the Constitution, resistance in all its forms, is the most sacred of [all] rights and the most imperative of [all] duties." This provision was not incorporated in the final text of the Constitution.

${ }^{33}$ Art. 147. This provision, however, is being construed rather narrowly. Where the accused claimed to be entitled, under this article, to resist prohibition of a newspaper and tho sealing of his printing rooms, the Bundesgerichtshof held [BGH, Urt. 9.7.1953-3 StR 212/52 (LG Frankfurt a.M.), reported in Neue Juristische Wochenschrift 44 (1953)], that the provision did not justify arbitrary action against a minor violation of the constitution by a single administrative act. The accused should have resorted to the specific remedies provided for by the Constitution for the orderly disposition of constitutional grievances. The court said that "government of laws" requires that Art. 147 be read in conjunction with these remedies.

${ }^{34} \mathrm{As}$ is well known, Léon Duguit was a staunch supporter of that right and believed it to be part of constitutional law even where it is not expressly included in the wording of the constitution. MaLÉzEeUx, Drort ConstrtutronNEx (1948), defines the right of insurrection as follows: "If the technical procedures, which are prescribed in order to assure the functioning of the democratic regine, function badly, those in power may be tempted to usurp the sovereignty of the people. Under these circumstances, the coup d'tat or the insurrection with a view to the reestablishment of the true sovercign should be considered as legitimate, even if not always as lawful."

35 The most forceful argument denying the inportance of the separation is that advanced by Professor Kessler, Natural Law, Justice and Democracy-Some Reflections on Three Types of Thinking about Law and Justice, 19 TUL. L. REv. 32, 56-57 (1944): "Law, to command 
point of view, that scientific purity is in itself a desirable end and, from the point of view of the adherent of natural law, that conformance to an ethical ideal should be judged only by the standards of the particular natural law that is being advocated. Another, and more important, answer is that a judge may wish to know-and the public is vitally interested that lie know-whether he is applying preexisting positive law or a preconceived idea of such law. ${ }^{36}$ Only when he is fully aware of the scope of his own freedom of choice, can he, with an open mind, reacli sucl issues as whether he ought to follow his own predilections or hunches, or rather conform to the notions of right and wrong prevalent in the commumity ${ }^{37}$ Knowledge of the exact extent of his freedom will make him realize the true scope of his law-creating responsibility. Sucl knowledge will render him free to substitute reasoning for rationalization.

III

\section{REASON VERSUS RATIONALIZATION}

The relativity of positive and natural law is both a logical necessity and a fact of experience.

Logic itself is a type of "natural law" which is logically inherent in all law, although in a different sense from that conveyed by the frequent assertion that law is based on "reason," that the common law is reason itself, or that the "law is a science." As pointed out previously, there is nothing inlerent in law which requires it to be logical, reasonable or scientific. This means that statutes, judicial decisions and other legal sources need not necessarily be logical, reasonable or scientific. They may be perfectly valid, even though they do not meet any of these requirements. However, a certain amount of logic is implicit in law, and particularly in law as evolutional reality. Law implies not only the logic expressed in language and nieaming, but also the logic which forces the resolution of contradictions. Perliaps the best example of that feature of law is that mentioned before,

obedience, has to live up to the 'ethical minimum' of a community. Furthermore, this critique of natural law philosophy [the positivist critique] is based on the unwarranted assumption that our legal system is closed and complete. In reality, due to the elasticity of the case law system, the courts are given considerable leeway in shaping the law according to their sense of justice, which in turn is imfluenced by the cultural pattern of the community and the moral tradition. Thus, the ideal is constantly becoming the positive. In the light of this phenomenon, the importance of the question whether the principles of higler law are really law, can easily be exaggerated. In the evolution of the common law system the opposition between positive and natural law is constantly overcome."

36 Professor Kessler's final analysis of the problem is well in point (id. at 60): "To bring the basic values of our civilization nearer to realization, more than a magical belief in natural law and in man's rational nature is necessary. To be sure, man is a 'rational animal,' but it is also true that he is constantly rationalizing irrational conduct, particularly aggressions."

37 On this dilemma see Cahn, Authority and Responsibility, 51 CoLUar. L. REv. 838 (1951). 
consisting in the fact that, when, in adjudging a concrete case, a court is faced with two contradictory rules of positive law, it cannot apply both but must resolve the contradiction. This feature of all law has its corollary in the prevalent, justified demand, formulated with respect to particular legal systems, that they "should be" logical, reasonable or scientific.

Both procedure and substance are "natural" to positive law. An ethical system may be static, but law is essentially dynamic, operating and developing in accordance with certain forms, however rudimentary these may be. The dynamic nature of positive law has its corollary in a specific ethical demand, commonly stated with respect to legal systems, that they be "workable," "operative" or "functional."

An ethical system may have no ethical substance, in that it may be nihilistic. But law must have some substance. This attribute of all law has its corollary in the specific ethical demand that law ought to be "just," "fair" or "equitable."

We have chosen to call the necessary attributes of law "jurisprudential natural law," which may be contrasted with "incidental" or "historical natural law." The term "historical" is used not in the sense of conveying the idea of a past event but $m$ the sense of a fact demonstrated by the history of law, past and present. History shows numerous incidents of "natural law" demands addressed to positive law.

As shown by the examples of "logic" developed into the ethical postulate of "reasonableness," of "procedure" expanded into the postulate of "functioning," and of "substance" carrying over to the postulate of "justice," there is, in experience, a link uniting the "necessary" or "jurisprudential natural law" with the "incidental" or "historical natural law." This link is established by those postulates addressed to law which, while not inherent in its nature, are uniformly, invariably, perhaps even umiversally, repeated. One might differ about the type of logic, the kind of procedure or the nature of justice, that should be incorporated in positive law, but no one will dispute that the law should be logical, workable and just. Even the eminent author of the much repeated paradox that "the life of the law has not been logic," would have agreed that law "should be" logical or reasonable. Most of us would disagree with those who believe that the law must function at all cost, but hardly anybody would dispute the proposition that the law should function. Even Machiavelli and Hitler expressed belief in "justice," however perverted their idea of justice might have been.

Legal history shows that the role of natural law in law has never remained limited to the necessary mimimum or even to the relatively larger area encompassed by the general demands for logic, functioming and justice. History records a constant interaction of positive and natural law. 
Natural law becomes incorporated into positive law, and is thus "denaturalized," and positive law, as soon as firmly established, tends to become a part of social ideology, so that it eventually appears to be selfevident or "natural." It then takes another form of "natural law" to counteract or destroy the "self-evidence" of positive law. Legal positivism itself has historically functioned as "natural law." 38 Proceeding from the proposition that any form of "natural law" is alien to the "nature of law"indeed, is not "law" at all-it has demanded that such law be eliminated. It has thus formulated the political idea of a "government of laws" as an idea inherent in law itself. It would be impossible, within the scope of an article, even to summarize the history of the cyclic development of law from natural to positive and beyond. But it may be possible to sketch some of the roots and general features of the interaction of the two types of law.

Perliaps the most important sources of the influence of "natural law" upon positive law are the social drive for mamtenance of the illusion of substantive, objective stability in spite of apparent change-essentially, for the illusion of security-and the human desire to shift moral responsibility. Natural law, as preexisting law, and especially as the universally valid, unchangeable and infallible law of God, of reason or of nature, appears to afford an ever reliable, objective standard of judgment. In the form of absolute law, it is a law that has "always been there"; in the form of relative law or of "natural law with variable content," it is a law which, at any rate, has "been there previously." It either requires no test or is assumed to have been tested before. If it has been hitherto unknown, that is merely due to our own blindness rather than to its fallibility. Such law does not invoke man's fear of the novel and of the unknown. It puts the mind at rest and gives men a sense of security. Even where it is, in effect, revolutionary, it creates the illusion of conservatism. Through its medium, many a revolutionary idea has passed unnoticed into the realm of positive law. It is thus a most convenient device - at times used unconsciously-of rendering law reform acceptable. ${ }^{39}$

In the case of judges, fear of the unknown and of the untested is combined with a reluctance to assume responsibility. A judge will more readily include in his decisions rules not supported by positive authority, where he believes them to be part of natural law, particularly divine law, the "law of reason" or "law of nature." For reliance upon "natural law" relieves him of the responsibility for creating the respective rules. It is easier for him to

38 For a more detailed discussion of the political idea of positivism see Sec. IV infra.

38 "It is an ancient 'ruse of world history' to present the law which it desires to introduce as already in force, and to present the law which it desires to abrogate as no longer in force. .. ." RADBRUCH, EINFUEHRUNG IN DIE RECHTSWISSENSCHAFr 32 (7th and 8th rev. ed. 1929). 
say "natural justice demands" than to say "I believe it to be right." And the judge's responsibility seems to decrease in direct proportion to the degree of the alleged certainty and infallibility of the asserted "natural law." Sucl responsibility is practically non-existent where the law invoked is said to be the law of God. It is more pronounced where that law is said to be ingrained in reason, in the demands of our civilization, in social necessity, in public opinion, etc. Lately, reliance upon the "laws of nature," in the sense of causal laws governing the universe, las beconie less common in accordance with our shaken belief in the absolute character of causality. In all these instances, however, the judge, in essence, claims to have "found" preexisting law, where in reality lie has created new law. Beingso he claims-merely a conduit of just, valid or existing law, lie is not responsible for the results of his decisions.

An identical plenomenon may be observed in the area of technical "law-finding," that is, in interpretation. As slown above, such "finding" is alleged to be merely reproductive, whereas it is always, to some extent at least, creative. It took jurisprudence a long time to discover the.creative element of interpretation, because that discovery placed judges in a position of responsibility which they were reluctant to assume.

It lias been noted that there is a greater need for natural law ideologies in democratic than in totalitarian societies. ${ }^{40}$ This may be due to the fact that the latter possess in the person of their liuman exponent, the dictator, a man who takes the sins of state agents upon himself. He may, in turn, shift his burden of responsibility to some idea, such as the good of the state or the welfare of the people. But to the totalitarian bureaucrat, he affords a perfect alibi. No such human alibi is available to the judge or administrative officer in a democratic society. For that reason, he turns to an abstract idea, such as "natural justice" or "the words of the statute," for justification. This, of course, does not mean that the social concept of "natural justice" is illusory or that "the words of a statute" have no objective meaning whatever.

Psychological conservatism is, on the other hand, also responsible for the ultimate human acceptance of positive law as "natural." People seldom go back to fundamentals, and when a legal rule has been in force for niany years, it never occurs to them that a different rule could be equally, or even more, just. Legal institutions exercise a profound influence upon our etlical judgment, and it nuay be observed that indignation, condemnation and contempt with respect to anything deviating from "our law" commonly arise even before the issue involved is analyzed. I have heard a French lawyer exclain, "Il n'y a pas de loi en Amerique," (meaning, that there

40 Kessler, supra note 35 at 53, 54. 
are no standards of legal judgment in America), because most of our law is judge-made, and an American lawyer indignantly assert that "there is no law in France," since stare decisis is not fully accepted, so that, in his words, "the judge can do whatever he wants."

While belief in natural law satisfies certain human needs, there are other luman needs which may be best expressed in the belief in strict positivism and legality or legitimacy, which may lead to legalism or formalism. We pride ourselves on being unemotional, on having a logical or scientific mind.11 Molière, caricaturing Les Femmes Savantes, depicts the wealth of emotions which are spent on being "scientific," and Shakespeare, in his Merchant of Venice, has presented the profoundly human, tragic element of formalism. ${ }^{42}$ As natural law affords the illusion of a "stable" isubstantive standard, so positive law satisfies that of a procedurally "fixed" standard, affording assurance that, wliatever change may occur, it will be performed by peaceful means. Stress on procedure, characteristic of positive law, appeals to the human desire for orderliness and routine, whicl miglit exclude violent change. And, of course, formalism too may be exploited for psychological purposes. A judge, afraid of his own emotional reactions to an issue before him, may resort to it, thereby shifting responsibility to "positive law." At times, this will result in so flagrant an injustice as to violate the spirit, if not the letter, of positive law itself..$^{43}$

It may be observed that frequently man's attitude toward natural and positive law is ambivalent. "True" continuity in spite of "apparent" change, expressed in natural law, and orderliness, expressed in positive law, are values whicl may be found combined in one human mind. The resulting

41 As Professor Fuller has noted in Reason and Fiat in Case Law, 59 HaRv. L. Rev. 376,379 (1946), "for many the term 'natural law' still has about it a rich, deep odor of the witches' caldron, and the mere mention of it suffices to unloose a torrent of emotions and fears."

42 Both Heine and Jhering felt that Shylock suffers an injustice. Jhering pointed out that Shylock becomes the victin of that very formalistic distortion of law of which he was himself guilty. Radbruch thought that while the decision in the case was right, its grounds were faulty. In fact, the play seems to caricature not Shylock but the operation of law. Portia, not Shylock, is a comic character. For even those who believe in the retaliatory function of law do not hold that justice should employ the same methods as did the criminal. No one suggests that the law should steal from the thief or defraud the defrauder. Yet, Portia too has her tragic moments. She, the mouthpiece of formalistic law, bitterly resents the fact that, in an effort to help a friend, Bassanio broke his vow of keeping her ring. In the ring episode Shakespeare brings to our attention the parallelism of juristic and moral formalism. He shows that they are rooted in the same human character. In choosing Portia as a spokesman of formalistic justice, Shakespeare certainly did not intend to pay a tribute to woinen. It has been frequently observed that Shakespearean women are not very intelligent. Compare MortesquIEU, Notrs SUR L'ANGIETERRE. Portia was not an exception.

43 For a striking example of the unfortunate results to which excessive formalism may lead, see Bernstein v. Van Heyghen Freres, 163 F.2d 246 (2nd Cir. 1947), cert. denied, 332 U.S. 772 (1947). 
ambivalence toward the conflict of positive and natural law plays a role in promoting a certain balance of control over legal systems by the two types of law. Such balance is achieved in phenomena of positive law, which combine positivist elements with flexible elements, opening the door to trends of natural law. ${ }^{44}$ It also finds expression in certain comprehensive legal institutions. The most important of these are recognized "customs and usages," customary law and lay justice.

In the light of the foregoing analysis, it may be pertinent to inquire whether a democratically minded individual is necessarily a positivist rather than an adherent of natural law. The answer is that while democracy postulates the rule of reason rather than rationalization, and personal responsibility rather than guidance by a fictitious natural law, it also calls for a critical approach to lawful authority. There is, therefore, no standard type of a "homo democraticus" or a democratic personality, in the sense of a rationalistic or positivistic psychological type, in contrast to the totalitarian imdividual guided by emotion or adhering to a philosophy of natural law.

IV

POLITICAL POSITIVISM: "GOVERNMENT OF LAWS"

Legal positivism, as a science of law, performs a limited, scientific function. It shows wherein the thinking of adherents of natural law has been animistic, magical and, at times, just mcorrect. It points out that they have, in fact, seen "God," "reason," or "nature," "ideal justice," "society," or "public opinion," behind simple legal operations, and that they have indeed endowed these concepts with a "legal soul" and with a "legal will" commanding obedience. It charges them with thinking that it is the tree-or perhaps a dryad-that makes branches grow, with substituting entity for function. ${ }^{45} \mathrm{It}$ shows that some of them have also, in a less dramatic manner, simply presented, as preexisting, rules which have not been theretofore part of positive law. As a critical philosophy, positivism makes agents of the law, particularly the judges, conscious of what they are actually doing. It renders their minds free by liberating them from the spell of legal magic operating under the guise of "natural law" and from misconception of the true nature of legal processes, and thus enables them to exercise a free will and to knowingly "choose" the course of their future action.

44 Note, for instance, that in American law, stare decisis, the most stable element of law, does not apply to its most stable branch, the Constitution. Smith v. Allwright, 321 U.S. 649 (1944). Compare Douglas (Mr. Justice Douglas), Stare Decisis, 49 Corusx. L. Rev. 735 (1949).

45 In freeing jurisprudence from the assumption of an "entity" where there is merely a function, positivism has performed a task similar to that which modern physics has accomplished by eliminating the theory of the "aether," as an entity permeating all space. 
However, a positivist is not only a man of legal science or a critical philosopher of law; he is also a citizen, perhaps a lawmaker, a judge or an administrator. As any other citizen, he may hold and promote political opimons. In this, he may not feel bound to follow the tenets of "positivism." He may, if he considers it desirable for the achievement of some political end, choose to use "the fiction of natural law" for the promotion of a political purpose. While intellectually rejecting the concept of "natural law," he may, nevertheless, utilize it in the belief that reliance upon such law will make his political views palatable to the people or to a group. Most of us will be ethically indignant over such perversion of truth for a political purpose. We hold that it is ethically improper for a man to preach natural law if he does not himself believe in it. We condemn such action as fraudulent or Machiavelhan. And, we beheve that, as a man of science, a positivist should not only refrain from deceiving people, but that he should indeed actively undeceive or enlighten them. Those of us who are positivists, that is, those who think that they have found the truth about natural law, feel morally bound to enlighten others, particularly those whose lack of enlightenment can do the most damage. Thus there is born the first basic ethical postulate of positivism. It consists in the ethical "mstruction to the judge" not to present as a magical entity or as in any sense preexisting a rule which is not, in fact, part of positive law. As thus conceived, the "instruction" amounts to not more than a demand requirmg the judge not to misrepresent facts or not to be himself deceived. It does not bar him from introducing new law, provided that he does so admittedly and openly.

Political positivism, however, usually goes much beyond that basic ethical "instruction." In its demand for a "government of laws," it condemns not only the fraudulent and fictitious but indeed any creation of law from inchoate sources or by inchoate methods. It postulates that all authoritative action be based on "laws," meaning legal rules which are formulated in general terms in advance of individual action.

Historically, the pohtical idea of "government of laws" was not a product of the philosophy of juristic positivism. The converse is more likely to have been the case; modern juristic positivism may have developed from pohitical positivism. "Government of laws" was not originally conceived as a challenge of the concept of natural law. ${ }^{46}$ It was rather directed at an eminently practical problem, the political organization of power. The aim was to find an effective method of checking the unlimited authority of the executive and the judiciary. To support that aim, in typically "natural

48 Although Montesquieu advocated vesting all legislative power in legislatures, he beheved in natural law. He advanced the cause of positivism, without being himself a positivist. See De L'Esprit des Lois, in 2 OEuvres Comprètes, texte presenté et annoté par Roger Caillois, Livre I, Ch. II, pp. 235 et seq., Livre XXVI, Chapter III and IV, pp. 752 et seq. 
law" fashion, the theory was invoked that judgments and executive acts are, by "nature," distinct from products of legislation, that is, general rules or "laws." This theory gave substance to the proposition that a clear-cut separation of the functions of the executive and the judiciary, on the one hand, and of the legislature, on the other, was possible. Assignment of these functions to different government agencies was deemed desirable, and their separation was therefore alleged to be feasible. Only much later were "laws," in the sense of "positive" laws or conscious formal legislative acts, setting a general standard of conduct, placed in opposition to "natural law" as a law not clearly defined but rather derived from inchoate sources and therefore implying arbitrary power. In due course, the political postulate of "government of laws" found expression in the jurisprudential tenet that only positive law is "law" pure and simple.

In addition to separation of powers, the idea of "government of laws," from its inception, also comprised another essential postulate, namely, that of legal security. This postulate demands that the law be settled uniformly in advance for all like cases, so that people may be able to know the laws by which their actions are to be adjudged. ${ }^{47}$ Again, whatever the original notion as to the nature of the law that is generally knowable, in due course the proposition was advanced that only positive law can be said to be a law settled in advance of action in such a manner as to be accessible to knowledge..$^{8}$ Thus, as separation of powers, so also legal security became predicated upon positive law.

The two component parts of the original concept of "government of laws," namely, separation of powers and legal security, are still dependent upon positive law and thus continue to be allied with positivism, in a different sense, however, from that assumed in arguments challenging that alliance.

It has been said that, as with the doctrine of natural law, so positivism may be used to justify any form of government. ${ }^{40}$ This is undoubtedly true if by "positivism" we mean a jurisprudential theory. However,

47 MontesQuIEU, id., Livre XI, Ch. VI, p. 399, demanded that judicial pronouncements be predetermined by laws to such an extent that they "never be anything but a specified text of the law." For-he said-were they "personal opinions of the judge, one would live in a society without precisely knowing the obligations which le contracts in it." Obviously paraphrazmg Cicero, Montesquieu continued, saying that judges are but "the mouth that pronounces the words of the law; inanimate beings who cannot modify either its force or its rigor." Id. at 404.

48 Many systems of natural law claim to be so knowable, but their claims are disputed. In positive law, of course, there are also large areas of dispute, but the majority of its rules are generally conceded to be known or accessible to knowledge. Also, adherents of natural law may assert that certain rules of positive law are not "law," but they concede that these rules are in existence as a positive phenomenon, whatever description they might choose to assign to it.

49 Fuller, Reason and Fiat in Case Law, 59 Harv. L. REv. 376, 389 (1946), states: "The school of natural law may be either reactionary or radical; the same is truc of the theory that all law is mere human fiat." 
if the antithesis of positivism and "natural law" is understood to be one of political philosophy, it will be found that only positivism can support a "government of law." For "government of laws" today actually means government of positive law, as the only law formally settled in general terms and generally accessible to knowledge in advance of individual action.

On the other hand, progress of positivist jurisprudence has produced a transformation and modification of the idea of "government of laws," rendering it a relative rather than an absolute idea, and thus, in effect, introducing into it elements of natural law. In its historical form, "government of laws" was based upon the notion that there is a "natural," clear-cut distinction between creation and application of laws. By virtue of this "inherent" distinction, it was thought possible to assign the two functions to different agencies without causing any confusion of authority, and, at the same time, to conceive of laws as securing advance determination and notice of the future disposition of any case that might arise. However, Rousseau had already compared the political proposition of placing law over men to an attempt at squaring the circle in geometry. ${ }^{50}$ Positivist jurisprudence has since brought to our attention the fact that the distinction between creation and application of law is not "inherent" or "natural" but man-made and relative. In the light of this realization, there can be neither perfect separation nor perfect advance legal determination of all mdividual cases. This does not, however, render either separation of powers or legal security meaningless. Only the scope of these postulates has thereby become limited. For the distinction between creation and application of law is not completely eliminated but merely modified. It is now considered to be one of degree between the more general and the more specific. The task is to find what degree of generality in a legal determination should be regarded as justifying its description as "general law" and, thus, its assignment to the law-making authority for purposes of maintaining separation of powers and legal security. The classification as "general" is no longer predicated upon any inherent quality of the respective legal determination, but is rather derived from the relevance of such classification to problems of separation of powers and of legal security. Since there can be no rigid formula for such classification, "government of laws" becomes a problem of reasonable adjustment and, to this extent, a problem of "natural law."

We have seen "positivism" develop from a merely formal concept,

50 Rousseau, Considerations Sur le Gouvernment de la Pologne, in 4 Orunges PosTHUMES 302. 
which suffices to perform the purely intellectual task of delimiting positive law from natural law, to a functional concept, involved in the ideological war with natural law for the conquest of the minds of men, and then emerge as a political concept, advocating the rule of positive law as a requirement of democratic freedom, in the sense of separation of powers and of legal security. The development does not end here. Political positivism, im one of its historical forms, raises a more specific problem: in continental Europe the question has been posed whether or not decisional law is a law "positive" enough to satisfy the requirement of legal security. This question has been normally discussed in conjunction with the more serious one: whether or not decisional law is consistent with separation of powers.

Montesquieu answered both questions in the negative. Indeed, the very core of his concept of separation of powers and of legal security was exclusion of judge-made law (or executive law). In the United States, however, where Montesquieu is supposed to have been most influential, there has never been much concern over the fact that the method of judicial law making, prevailing under the common law, is inconsistent with the notion of separation or of legal security. ${ }^{51}$ Early cases dealt with limitations upon the powers of the legislature ${ }^{52}$ rather than with restrictions upon the growing influence of judges. The reason for this unconscious departure from the pattern set by Montesquieu may perhaps be found in the belief that the common law is not "made" at all but rather preexisting, that it is a "natural law" to be "found" or "declared" rather than "created." Until the present time, no attempt has been made to formulate a conceptual definition of the area reserved to the legislative power, and the problem of separation, in the sense of protection of the power of the legislature against judicial encroachment, remains limited for the most part to fields which are preempted by statutory law. The discussion of "legal security" is confined to the question concerning the validity and scope of stare decisis.

By contrast, in continental Europe, in accordance with the original

51 There have been occasional expressions of concern over the power of courts to declare that a rule of the common law is not appropriate to the situation prevailing in this country, accompanied by suggestions that abuse of such power may be an usurpation of legislative authority by the courts. See dissenting opinion of Caton, J., in Seeley v. Peters, 10 Ill. 130, 149 et seq., 157 (1848). For an early view favoring codification and suppression of the Common Law of England see SAarpson's Discourse (1826). Sanipson believed that only codification and subjection of judicial decisions to legislative sanction could result in "The Departments of Government to be ... kept within their respective splieres-the legislative not judging, nor the judiciary making laws. ..." Id. at 64. On Jefferson's views concerning the need to curb judicial freedom see Waterman, Thomas Jefferson and Blackstone's Commentaries, 27 Irr. I. REv. 629 (1933).

52 Taylor v. Porter, 4 Hill (N.Y.) 140, 40 Am. Dec. 274 (1843); Trustees of the University v. Foy, 1 Murpley (N.C.) 58, 3 Am. Dec. 672 (1805). 
pattern, both separation of powers and legal security were believed to be tantamount to one formula, the exclusion of judicial law making (or executive law making). This, in turn, meant the exclusive rule of statutory law. ${ }^{53}$ Under the influence of the libre recherche trend and under the impact of the recent contact with Anglo-American law, this position has been, to some extent, modified. ${ }^{54}$ In Germany, decisional law is still believed to be

53 In Germany, of course, statutory law is understood in a broad sense. "Gesetz" (statute) is read to include customary law. Compare ENNECCERUS-NIPPERDEY, supra note 4 at 157. But customary law today is developed mostly in the field of procedure in the form of consistent adjudication. See I Staddingers KoMmMentar zUM BuERgeritchen GesetzbucH 26 (11th rev, ed. 1954).

An incident of the "rule of statutory law" is particularly concerned with the problem of "correct" statutory interpretation. "Correct" interpretation, however, has not been the same in all fields of law or throughout history in identical fields. Compare art. 1 of the Swiss Penal Code with art. 1 of the Civil Code. Also, in criminal law the Swiss Federal Tribunal, in the course of time, changed its views with regard to the proper interpretation to be applied in order to safeguard legal security. It appeared that legal security is an ambiguous concept; it may mean protection of individual reliance upon a certain interpretation or uniformity of adjudication. See Procurear général du Canton de Neuchâtel contre Strautmann, decision of the Federal Tribunal of Oct. 1, 1943, reported in ENTSCHEIDUNGEN DEs SchWEIzERISCHEN BUNDESGERICHTS, Amtliche Sammlung, vol. 69, Part IV, p. 178, at pp. 179, 180 (cited BGE 69 IV 178). The Tribunal formerly took the position that a criminal statute must be construed strictly in favor of the accused. See Schweizerische Bundesanwaltschaft gegen Arnold, BGE 48 I 441, 443 (1922); Bundesanwaltschaft gegen Christ, BGE 51 I 159, 161 (1925). It has later adopted the view that the "correct text" (le texte juste) must be sought and uniformly apphed to all. See Strautmann case, supra; also Mariot contre Ministère public du canton de Genève, BGE 70 IV 81 (1944); Graf gegen Staatsanwaltschaft des Kantons Zurich, BGE 79 IV 33 (1952). In the Strautmann case the Tribunal poimted out that "apphication of the text which constitutes the law ( $q u$ i doit faire loi) is not contrary to the principle nulla poena sine lege (art. 1, Penal Code). For it is in the 'correct' text that 'the law is contained." "The fact that the perpetrator had no knowledge of that text-the court continued-is irrelevant except with regard to the problem of his guilt. He may have recourse to the provisions of the Swiss Penal Code concerning error or law (art. 20, Penal Code). The meaning of the law, however, inust be uniform for all.

The problem has also been raised to what extent the choice of certain methods of interpretation, such as the use of preparatory works in aid of construction and the use of contemporaneous construction, bears on the issue of legal security. There is a tendency to use preparatory works sparingly, since it is believed that such use carries an element of uncertainty, in view of the inchoate manner in which statements of legislators are often made. See discussion in Pfenninger, Zehn Jahre Schweizerisches Strafgesetzbuck, in SCHWEIZERISCHE JURISTEN-ZEXTUNG, 217 and 237 , pp. 220 et seq. (1953). Preparatory works may be used but are not binding. See cases cited in Gratann, Schweizerisches Strafgesetzbuch, note to Art. 1 (1947). As to the use of preparatory works in aid of construction and of contemporaneous construction, the Tribunal in the Strautmann case said that the methods of statutory interpretation are the same in criminal and in civil law.

54 Actually, in recent times there has been an enormous development of decisional law in Germany. The extent to which it has been accepted as a source of law may be seen from the fact that error of law has been admitted as a defense in criminal cases by a decision of the Great Senate for Criminal Matters of the Bundesgerichtshof, notwithstanding silence of the Penal Code on the subject. See decision of the Bundesgerichtshof of May 18, 1952 (BGHSt. $2,194)$. Of course, this decision purports to "interpret" the Penal Code. 
incompatible with separation of powers, but the belief that legal security absolutely precludes all judicial law making has been shaken. ${ }^{65}$

While Montesquieu's ideal of a "government of laws," in which the judge is merely "the mouth that pronounces the words of the law," is not realized anywhere, it may be interesting to compare the development of law in the various systems against that ideal. In the course of this comparison there will be occasion to present the diverse ideas on "government of laws" in their relation to positivism or natural law.

As formulated by Montesquieu," "government of laws" postulates the ideal of a complete and closed legal system, in which there are no gaps, so that all questions can be answered without recourse to inchoate sources and judicial discretion is ruled out. The system, though believed to have been discovered in England, was adapted to the situation in continental European countries. While in continental Europe Montesquieu's version of a "government of laws" is still felt to be a relatively valid ideal, no legal system realizes it even to the extent that that might be logically possible. Whereas, as shown above, some law creation by judges is implicit in the logic of adjudication, so that Montesquieu's postulate is to this extent illusory, it is logically possible to conceive of a system of code law which would reduce law creation by judges to a necessary minimum. In terms of positive law, this could be accomplished by adherence to a legal rule providing that where an action finds no warrant in the express and specific terms of a statute, interpreted strictly, judgment must be for the defendant. ${ }^{57}$ None of the civil code systems of continental Europe has realized such a rule..$^{58}$ The Swiss Civil Code ${ }^{59}$ contains an express provision for the filling of gaps in law by judges. ${ }^{60}$ Admission of custom and customary law,

55 Compare decision of the Federal Constitutional Court. See note 16 stepra.

56 Compare note 47 suspra.

57 MontesQuIEU, Livre VI, Ch. III, p. 311, states: "In despotic states there is no law at all: the judge is himself the rule. In monarchies there is a law, and wherever it is clear, the judge follows it; where it is not, he looks for its spirit. In a republican government it is of the essence of the constitution that the judges apply the letter of the law. There is no citizen against whom one could interpret the law where his property, honor or bife is involved."

Of course, a rule such as that stated in the text would not afford an absolute guarantee against use of inchoate sources by judges. For they could violate the rule or distort facts of a case and thus fit them into existing legal provisions by which they were not otherwise covered.

58 That rule is frequently proclaimed in penal statutes. See art. 1, of the Swiss Penal Code. However, as may be seen from the discussion in note $\mathbf{5 3}$, even that rule is susceptible of being interpreted broadly or narrowly. See Procureur général c. Strautmann, supra. It should be noted in this context that, when referring the accused to the defense of error of law, the court did not accord him a privilege as broad as the one he would have enjoyed under a narrow interpretation of the statute itself. For the defense of error of law is of limited scope.

59 Art. 1, Civil Code.

60 In contrast to the German Civil Code, which was purported to regulate all details, the Swiss Code was formulated in "the belief in the creative power of the sense of justice." EcGER, UEBER DEE RECHTSETHIK DES SCHWETZERISCEIEN ZivHGESETZBUCHEs 83 et seq., 90-91 (1939). 
in addition to statute, of analogy to a particular statute or to the principles of an entire statutory system, ${ }^{61}$ of the concept of "acting in fraud of the law, ${ }^{22}$ and express statutory provision forcing the judge to decide even where he admittedly does not understand the statute, ${ }^{63}$ as well as other devices, render the codes by no means closed but rather open.

In recent years there has been a noticeable expansion of judicial legislation in Germany. ${ }^{64}$ The jurisprudential attitude toward that expansion, however, is still rather ambivalent. The Federal Constitutional Court of the Bonn Republic recently dealt with the relationship of judicial legislation-which it expressly held to be an outgrowth of natural law-both to "separation of powers" and to "legal security." ${ }^{-5}$ Significantly, it assumed that the Rechtsstaat-the German equivalent for "government of laws" 68 -implies legal security but does not necessarily imply separation of powers. The court said that while the Rechtsstaat, being essential to legal security and peace, belongs to the "fundamental provisions of the Constitution" and is a "genuine postulate of justice" (meaning, "natural" justice), separation of powers is merely a "fundamental organizational principle." Accordingly, in the opinion of the court, delegation of legislative authority to courts-even where such delegation is contained in the written Constitution - which disregards the principle of legal security to a degree where "the resulting legal chaos" is "outright intolerable," would be "unconstitutional," but "it is doubtful" that a violation, however far-reaching, of the principle of separation of powers by the original framers of the Constitution could ever result in unconstitutionality. The court thus expressed the belief that judicial legislation does encroach upon the principle of separation of powers but does not necessarily result in legal uncertainty. It pointed to the numerous examples in which, on the basis of statutes, rules were

61 The distinction is referred to in German under the label of Rechtsanalogie as against Gesetzesanalogie.

62 This concept, known in continental European jurisprudence under the name "in fraudem legis agere," was thus defined by the Roman jurist Paul (Digest 1.3.29): "Contra legem facit qui id facit quod lex prohibet, in fraudem vero qui salvis verbis legis sententiam eius circumvenit." As defined by Vetsch [DIE UMGEHUNG DES GeSETZES, in fraudem legis agere (1917)], "Circumvention of the law is an act which, while not directly violating a provision of the law, frustrates its purpose." On this concept see Rotondr, GLI ATtr IN Frode ALIA LegGe NeLiA Dottrnia Roseana e Netta sua Evoluztone Posteriore (1911).

${ }^{63}$ See art. 4, French Civil Code.

B4 Coinpare note 54 supra.

65 Decision of December 18, 1953, cited supra note 16.

66 The term Rechtsstaat means a State all of whose acts are governed by law. It is sometimes understood to mean a State whose sole function is "law" enforcement, preservation of peace and order, in contrast to a "Welfare State." It is apparently not understood to have the latter connotation in present-day German constitutional doctrine, for the Bonn Republic is referred to both as a "Social State" (art. 20 of the Constitution) and as a "Rechtsstaat." 
developed by judicial interpretation without creating legal chaos. ${ }^{07}$ It nevertheless held that, if legal security is to be maintained, judicial legislation must not go too far. It is admissible only to the extent that judges are not called upon to make decisions depending on their personal philosophies and political views. Delegation of policy determinations to judges would, in the opinion of the court, result in legal uncertainty. In this view, legal security is inconceivable except on the basis of statutes, ${ }^{08}$ which must be the ultimate source of all legal action. Common law actions are excluded. The judicial function is restricted to "subsumption, interpretation and the filling of gaps." Thus, the German Rechtsstaat, in ultimate analysis, is still conceived as essentially a "Gesetzesstaat," or government based on statutory law. Such government, of course, is a positivist ideal, which strangely conflicts with the supreme rule of natural law theoretically professed by the court. ${ }^{88}$

In another case, the highest court of the Bonn Republic in civil and criminal matters (Bundesgerichtshof) ${ }^{70}$ in dealing with the question of the scope of authority to be accorded to decisions of the Federal Constitutional Court, discussed the problem of the relationship between stare decisis and the Rechtsstaat idea, both from the standpoint of separation of powers and from that of legal security. ${ }^{71}$ The issue before the court was whether-apart from those cases in which decisions of the Constitutional Court have the same effect as a statute-binding force is to be attributed solely to the judgment rendered by that court or also to the grounds of decision. ${ }^{72}$ In arriving at the conclusion favoring the former alternative,

${ }^{67}$ Of the examples cited by the court the most representative is the reference to the development of the statutory term "good faith" by judicial interpertation.

es As to the meaning of that term, see supra note 53 .

69 Of course, "government of laws" has been frequently proclaimed as a demand of natural law. This is one of the paradoxes of natural law.

70 Note that there are several "supreme courts" in Germany. The "Bundesverfassingsgericht" or Federal Constitutional Court is a special tribunal deciding constitutional issues. The "Bundesgerichtshof" or Federal Tribunal is the court of last resort in civil and criminal matters. The case discussed above was decided by the former court; the case now at issue was decided by the latter court.

71 Decision of May 20, 1954. BGH, Beshl. des Grossen Zivilsenats v. 20.5.1954, 13 ENTschemUngen Des Bundesgericet Des Shofes In Zivinisachen 265 et seq. (1954) (cited BGHZ 13, 265).

72 The case arose under subdivision (1) of section 31 of the Law of March 12, 1951, concerning the Federal Constitutional Court (BGBl. I S. 243) rather tban under subdivision (2) of the same section. The former deals with the effect of decisions of the Constitutional Court generally, whereas the latter deals with the special effect attaching to those decisions of the court which dispose of "arguments or doubts . . . concerning the compatibility of federal or state law with the constitution or of state law with federal law," with the "compatibility of a federal or state statute with the constitution or of a state statute or other state law with a federal statute," with "doubts concerning the question whether a rule of international law constitutes part of federal law," and "arguments concerning the continued validity of a law as federal law." 
the Bundesgerichtshof pointed out that acceptance of the latter alternative would violate both legal security and separation. It emphasized that the enunciated limitation "conforms to the compelling demand of legal security," for "it would be incompatible" with such security "to attach binding force to decisional considerations, as to which it might be most doubtful in a concrete instance whether they belong to the 'decisive' grounds of decision or are of importance only incidentally, in a way, as supporting grounds." The court further elaborated that due to the element of general uncertainty inherent in decisional law-derived from the fact that often it may be doubtful what has been decided-German law has, apart from exceptional provisions, ${ }^{73}$ abstained from accepting stare decisis in the form of a binding legal rule; ${ }^{74}$ judicial decisions, even those of upper courts, are followed by other courts and government agencies only as a matter of free choice and merely by virtue of "their inherent convincing force, not however by way of legal compulsion."

The court pointed out ${ }^{75}$ that-since decisions of the Federal Constitutional Court are binding not merely inter partes and indeed have an effect somewhat similar to that attaching to statutes $-{ }^{76}$ this very effect, exceptional in scope and assimilating the functions of the Constitutional Court to those of the legislature, necessitates-if separation of powers be maintained-a limitation of the substantive area of obligation. The Constitutional Court must remain a court; endowing its grounds of decisionthe broad principles upon which it might base its judgments-with authority would transform it into a legislative body. ${ }^{77}$

Section 13(6), (11), (12) and (14). In the last enumerated instances, by the very terms of the statute [lex cit. section 31(2)], the decisions of the Constitutional Court have the same legal effect as a statute. In cases other than these, the statute merely provides that decisions of the Federal Constitutional Court bind all constitutional authorities of the federal and state government as well as all courts and agencies. This means that, $\dot{m}$ contrast to other court decisions, they bind not merely inter partes. The issue before the Bundesgerichtshof in the case at bar, however, was not who was bound by the decision of the Bundesverfassungsgericht but rather how much of the decision was binding.

73 The exceptions are contained in Section 136, Gerichtsverfassungsgesetz, cited in note 4 supra, and in Section 31(2) of the law cited in note 72 supra.

74 Note 71 supra at 279 et seq.

75 Ibid.

${ }^{78}$ The court expressed the view that even those decisions of the Constitutional Court which are not expressly endowed by law [section 31(2) of the Law of March 12, 1951, cited sutpra, note 72] with statutory force have an effect similar to that accorded to a statute, since they bind all authorities [section 31(1), lex cit.]

77 In this context, the court dismissed an argument advanced by legal writers, pointing to the situation prevailing in the Anglo-Saxon legal system; it said at 282, "There (in AngloSaxon countries) -in exact contrast to the German legal system-courts have a far-reaching law-creating and not merely an adjudicating authority. However, even there the binding force of grounds of decision is strictly himited to the concrete situation, as submitted for decision." 
In the case of the common law, the very nature of law creation precludes even approximation to Montesquieu's version of a "government of laws." Case law is necessarily ex post facto. As pointed out by Bentham, ${ }^{78}$ it first permits man to commit an act and then punishes him for committing it. Accordingly, in England, the homeland of the common law, the desire for legality has been expressed in the demand for a "Rule of Law" "rother than for a "government of laws." "Rule of Law," as has been stated, ${ }^{80}$ "establishes in truth no more than the organization and procedure by which liberty is protected against illegal incursion." ${ }^{\text {81 }}$ Supremacy of Parliament is said not to be one of the bases of English law in the same sense as is the concept of liberty. The argument has even been advanced that the courts are the ultimate bases of legal authority, for they interpret statutes. ${ }^{82}$

Yet, the concept of "government of laws," in the sense of affording legal certainty, may be as meaningful in common law countries as it is in code countries. Thus, Story understood by "government of laws" a government of precedents, meaning stare decisis. ${ }^{83}$ Indeed, such government, in an important respect, fulfills the demand for security, in the sense of predetermination by a previously established legal rule, better than does government by statutes. Case law lends itself to a greater specification than does statutory law. Once a precedent is available, the discrepancy between the universal and the particular is sinaller than in statutory law.

Since in modern times precedents are inostly available, cases of first impression being rare, it would seem that the problem of legal security under a system of judicial law making is parallel to that problem under a system in which the prevailing method of legislation is by statute. That, however, is not quite correct, due to the essential difference in the tech-

78 In Justice and Codmetcation Permitons (1829), Petition for Codification, p. 2, Bentham states: ". . . the truth is-that, on each occasion, the rule to which a judge gives the force of law, is one which, on this very occasion, he makes out of his own head; and this-not till the act for which the man is thus dealt with has been done: while, by these same judges, if the same thing were done by the acknowledged legislature, it would be spoken of as an act of flagrant injustice, designated and reprobated, in their language, by the name of an ex post facto law."

79 See Dicey, Introduction to the Study of Law of the Constitution, Part II (9th ed. 1939).

80 Graveson, The Bases of Modern English Law, 61 JuRIs. Rev. 242, 250 (1949).

81 This organization and procedure, of course, is established by general positive law, whether statutory or decisional. However, that law covers merely a limited portion of the legal system.

${ }^{82}$ This is maintained in theory in spite of the fact that, again tbeoretically, Parliament could abolish the courts.

831 Story, Comareararies on the Constitumon of THE, United States 279, 280 (5th ed. 1891). 
nique of case and statutory law. ${ }^{84}$ Changes in statutory law are, as a rule, required to be made in accordance with certain forms, whereas changes in the common law may be made unconsciously and gradually. The method of differentiation and of overruling of precedents renders the case system, as a general rule, more flexible than a statutory system. ${ }^{85}$ Prediction of the future disposition of individual cases is, to this extent, more difficult under the former system than it is under the latter. Therein hes the lesser security of the common law. In recognizing the necessary flexibility of the common law, political positivism in this country postulates not a rigid but a substantial abiding by precedents. Undoubtedly, when supplementing statutory law, judicial legislation increases-legal certainty.

As shown above, separation of powers in this country has never conformed to Montesquieu's pattern. Indeed, perhaps Montesquieu's acceptance in this country was no less a paradox than his behef to have discovered the principle of separation in the Enghish Constitution. ${ }^{86}$ However, it is quite possible that the future development of law will lead to a reversal of the relative positions in the Uinited States and in continental Europe with regard to separation of powers and its place within a system of "government of laws." 87 In Germany, for instance, with increasing acceptance of

84 The method of following precedents is more complex than is the method of applying statutes. The former method implies, as a first step, an inference of a rule from the case to be used as a precedent, whereas in the case of statutes the rule to be applied is, generally, a priori available.

85 It should be noted that the method of law making traditionally prevailing in a country affects all phases of its law and of its legal thinking. Thus, in continental European countries even stare decisis sometimes has a statutory basis. Compare notes 4 and 72 supra. In common law countries, on the other hand, the rule of precedents is so deeply ingrained that judges will invoke a precedent to justify their authority to overrule a precedent. Legal Tender Cases, 79 U.S. (12 Wall.) 457,554 (1870).

80 In the United States, particularly under the constitutions of the several States, separation of powers between the legislature and the judiciary has been held to be a requirement of "free government" and as "essential to the maintenance of a republican form of government." People ex rel. Sutherland v. The Governor, 29 Micli. 320 (1874). It has thus been held that justices of the peace, who are vested with judicial power, could not be appointed by statute to be members of the township board, whose duties are legislative and administrative in character. Dearborn Twp. v. Twp. Clerk, 334 Mich. 673, 55 N.W. 2d 201 (1952). But there has never been any concern over the fact that judges in Michigan, as in all other States, actually make laws within the scope of the common law. There has been considerable concern, on the other hand, over the integrity of judicial power. Thus, in State v. Garnetto, 75 R.I. 86, 63 A.2d 777 (1949), the Supreme Court of Rhode Island held unconstitutional a mandatory act directing and compelling a court to quash a sentence previously imposed, as being a legislative interference with the judicial power.

87 It may be significant to note that the term "governinent of laws" linguistically suggests the meaning of "government by statutes." The common law is usualy referred to in the singular "law" rather than in the plural "laws." On the other hand, the German term "Rechtsstaat" suggests "government by law" rather than "government by laws," for which the Gerinans would use the term "Gesetzesstaat." 
judicial law making, separation of powers is being detached from the Rechtsstaat. By contrast, in the United States, with the recent expansion of statutory law, it is believed that separation of powers will increasingly become a problem of "government of laws." Perhaps a first indication of this trend in the United States may be found in District of Columbia v. Thompson $\mathrm{Co}_{0}{ }^{88}$ holding that separation of powers precludes the repeal of a statute by any method other than legislative.

To what extent has the development of the idea of "government of laws," in the sense of separation or of legal security, been recently affected in the various countries by either positivist or natural law doctrines? It is rather difficult to give a clear-cut answer to this question, although several observations may be pertinent.

In the United States, judicial law making is no longer considered to be a product of natural law. The problems of separation and of legal security have, nevertheless, remained largely unchanged. In Germany, on the other hand, judicial law maknig is still considered to be a direct expression of the ideology of natural law. At the same time, courts express a great concern with problems of separation and of legal security, resulting from the expansion of such law making. In the United States, independent legislation by common law is on the decline, that law being overshadowed by the unparalleled expansion of statutory law. This development is accompanied-at least in judicial decisions--by adherence to the jurisprudential positivism of Justice Holmes. In Germany, on the other hand, there is an enormous expansion of judicial law making, and this phenomenon is accompanied by a growing belief in natural law.

Positivism everywhere is undergoing a serious crisis. In continental Europe, the libre recherche trend for a while seemed to disrupt the traditional statutory system and introduce a "kingdom of judges," carrying the idea prevailing in Europe that such a kingdom constitutes a rule of natural law. The present German doctrine of "super-legal law" may be merely a temporary reaction to the arbitrary rule of "positive" law under the Nazi regime. Its appearance at this stage, however, demonstrates the fact that in times of constitutional crisis there is a tendency to resort to "natural law."

"Government of laws," as a specific demand of political positivism rather than as a postulate of natural law, however, still has an important function to perform. Indeed, its significance for the future development of law in the United States may be greater than in other countries. For in view of the enormous expansion of statutory law, the task before us is to make our statutes work, that is, to make them work "as statutes." Only

88346 U.S. 100 (1953). 
positivism can clarify the nature of that task, for, in contrast to natural law which emphasizes "just" meaning, positivism stresses "correct" meaning. Thus, positivistic jurisprudence is particularly concerned with problems of technique and procedure which may help in elaboratimg and applying such meaning.

As particularly emphasized in Switzerland, ${ }^{89}$ government of statutory law is predicated upon a correct understanding of statutes. Such understanding, in turn, is in large measure dependent upon good draftsmanship. In order to be meaningful, statutes must be written in such a manner as to be understandable. Unfortunately, the quality of our statutory draftsmanship has not measured up to that of our judicial decisions. ${ }^{90}$ We seem to believe that we can best realize the principle of "government of laws" by making our statutes unduly verbose and casuistic. This method works as a double-edged sword. While some problems of interpretation may be eliminated, others are created. Perhaps it is time for us to recognize that statutory law cannot operate in the same manner as does case law, and that it is not necessary that it operate thus. For, under our system, a judicial decision interpreting a statute becomes part of that statute and thus specifies its meaming. No statute can, without becoming obscure, itself perform the task of specification as well as a judicial decision. "Government of laws," in the hight of this realization, must hence be understood in a twofold sense: as a government by general law expressed in statutes, and as government by its specified meaning, incorporated in interpretative judicial decisions.

In the development of statutory draftsmanship-a logical prerequisite of meamingful statutory law ${ }^{91}$-combined with statutory interpretation by intelligent judges who are conscious of the true nature of their function and aware of the hine of demarcation, however vague, that exists between positive and natural law, lies the future of a "government of laws," the future of positivism.

89 Compare supra note 53.

90 In preparing briefs to be submitted to courts, attorneys analyze, ponder and weigh every word. Any document issuing from the Federal Government is revised and edited. A law review article is carefully edited and revised by student law editors, who have no counterpart in any other country, and of whom American law schools are justly proud. Some of our judicial decisions are masterpieces of literature. There is-it may be safely said-only one type of legal writing in this country in which draftsmanship seems to be utterly neglected, and it is the type of writing in which proper draftsmanship is more essential than in any other field, namely, statutes.

In our Trading with the Enemy Act of 1917, 40 Stat. 411, as amended, 50 U.S.C. App. $\S \S 1-40$ (1952), there is one section ( $\$ 9$ ) which fills nine columns, and in this section there is a single sentence (subdivision b) which fills four columns.

91 There is also a great need for rules of interpretation, which might facilitate the drafting and understanding of statutes. See Silving, A Plea for a Law of Interpretation, 98 U. PA. L. REv. 499 (1950). 